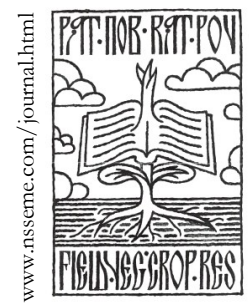

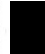

\title{
Comparison of Biplot Analysis and Kang's YSi Statistic in Estimating Maize Hybrids Stability
}

\author{
Miroslav Zorić · Bojan Mitrović · Dušan Stanisavljević • Mile Ivanović · \\ Goran Bekavac $\cdot$ Dalibor Živanov $\cdot$ Milan Mirosavljević
}

\author{
received: 3 June 2014, revised: 25 September 2014, accepted: 7 November 2014 \\ published online: 6 February 2015 \\ (C) 2014 IFVC \\ doi:10.5937/ratpov51-6208
}

\begin{abstract}
Summary: Integration of mean yield and stability evaluation into a single analysis is practical for maize hybrids recommendation and approval in multi-environment trials. The objective of this study was (i) to investigate grain yield performance and stability of 21 experimental maize hybrids via the use of the Kang's yield-stability statistics (YSi) and via the sites regression biplot (GGL) from multi-location trial conducted in Serbia; and (ii) to determine if hybrids yield stability was influenced by the linear effect of an environmental index. Hybrid main effect was highly significant and captured $9 \%$ of total sum of squares. Hybrid $\times$ location interaction was highly significant and accounted for $8.1 \%$ of the total sum of squares. Heterogeneity caused by environmental index was statistically non-significant. The same genotypes were recognized as stable by YSi and GGL biplot, but we recommend the sites regression biplot as more informative and precise tool for simultaneous hybrids mean performance and stability estimation.
\end{abstract}

Keywords: GGL biplot, grain yield, hybrids, maize, yield stability, YSi statistics

\section{Introduction}

The phenomenon of genotype $x$ environment interaction (GEI) is characteristic of multi-environment trials (MET) and represents permanent interest for breeders and biometricians along with practical and theoretical aspects (Kempton \& Fox 1997). Genotype stability estimation and GEI are specifically interrelated. While it would be nearly impossible to package into one cultivar all highyield genes and genes conditioning all possible stresses that might be encountered from location to location and year to year, identification of cultivars that are both high yielding and stable in performance across multiple environments (locations or years or locations-years combination), or that have specific adaptation, is an appropriate strategy (Kang et al. 2005). Grain yield is a quantitative trait and routinely exhibits GEI, and as it represents agronomically and economically most important trait in maize, different genotypes should be evaluated across multiple environments in the advanced stages of selection (Annicchiarico 2002).

The effects of genotypes and environments are statistically non-additive, which means that

M. Zorić · B. Mitrović* · D. Stanisavljević · M. Ivanović · G. Bekavac · D. Živanov $\cdot$ M. Mirosavljević

Institute of Field and Vegetable Crops, 30 Maksima Gorkog, 21000 Novi Sad, Serbia

e-mail: bojan.mitrovic@nsseme.com differences between genotypes depend on the environment or in other words differences between environments are not the same for different genotypes (Comstock \& Moll 1963). GEI indicates importance of environments and their variable factors on adaptability and stability and is favourable phenomenon only if it is correlated with above-average yield (Yan \& Hunt 2003). The environmental index is believed to represent a majority of the differences among locations, which includes differentials in fertility, cultural practices, insect or disease incidence, humidity, insolation, etc. (Haynes et al. 1995). The differences could relate to the growing season and/or to the period just before the growing season. Information on individual environmental covariates, including environmental index is needed to understand the nature and causes of genotype $x$ environment interaction as well as to exploit it (Kang et al. 2005)

The estimation of performance and stability becomes important to identify consistentperforming and high-yielding genotypes. Various concepts of stability are described (Becker \& Leon 1988). In varying environments, genotypes that provide high average yields with minimum GEI have been gaining importance over increased yields (Gauch \& Zobel 1997).

Acknowledgements: The authors gratefully acknowledge Protection and Recognition of Varieties Department of Ministry of Agriculture, Water Management and Forestry of Republic Serbia for cooperation in this study. 
The sites regression model (SREG) (Crossa \& Cornelius 1997) expresses the empirical mean of the $i_{\text {th }}$ genotype in the $j_{\text {th }}$ environment, as a sum of linear (additive) components (i.e. main effects of locations), a sum of bilinear (multiplicative) components combining the effects of genotypes $(G)$ and genotype $\times$ environment (GE), and a residual error. Yan et al. (2000) referred to biplots based on singular value decomposition (SVD) of environment-cantered or within-environment standardized GE data as "GGE biplot" and this term emphasizes that the understanding of both $G$ and $\mathrm{GE}$ is relevant to genotype evaluation and must be considered simultaneously for appropriate genotype and test environment evaluation.

The yield-stability statistic $\left(\mathrm{YS}_{\mathrm{i}}\right)$ proposed by Kang (1993) represents modified rank-sum method (KRM) (Kang 1991) but is less likely to commit Type II errors (choosing a genotype for cultivation when it is unstable in its performance) relative to selection for both yield and stability. Stability component in $\mathrm{YS}_{\mathrm{i}}$ is based on Shukla's (1972) stability-variance statistic $\left(\sigma_{i}^{2}\right)$, which provides the contribution of a genotype to the total GE interaction, attributable to all genotypes in the test (Kang 1993). The $Y_{S_{i}}$ was first applied in maize (Magari \& Kang 1993) and soybean trials (Pazdernik et al. 1997). Madry (2003) used $\mathrm{YS}_{\mathrm{i}}$ in a series of yield trials of spring wheat and oat to investigate it possible use as a sufficient selection index for selecting generally adapted genotypes. Investigation of yield stability of coolseason pasture grasses by $\mathrm{YS}_{\mathrm{i}}$ was conducted by Waldron et al. (2002); of rice (Oryza sativa L.) cultivars by Gravois \& Bernhardt (2000); of potato (Solanum tuberosum L.) seed families by Upadhya \& Cabello (2000a,b); of common bean (Phaseolus vulgaris L.) genotypes by Mekbib (2003).

The objective of this study was to (i) investigate grain yield performance and stability of experimental maize hybrids via the use of the Kang's $\mathrm{YS}_{\mathrm{i}}$ statistic and via the SREG biplot analysis from MET conducted in Serbia; and (ii) determine if hybrids stability was influenced by the linear effect of environmental index.

\section{Material and Methods}

Genetic material used in this research was represented by 21 experimental maize hybrids tested in official variety trials organized by the Department for Protection and Recognition of Varieties of Ministry of Agriculture, Water Management and Forestry of Republic Serbia during 2004. Experimental data were mean grain yields $\left(\mathrm{t} \mathrm{ha} \mathrm{a}^{-1}\right)$ of tested hybrids over eight locations. The names of the test locations used are shown in Table 1 along with their codes, latitudes and longitudes.

Table 1. Test locations and climatic variables involved in maize multi-location yield trial during 2004. Average values for the period April to October 2004 meteorological series.

\begin{tabular}{|c|c|c|c|c|c|c|c|c|c|}
\hline Location & Code & Latitude & Longitude & $\begin{array}{l}\mathrm{T}_{\max }{ }^{\dagger} \\
\left({ }^{\circ} \mathrm{C}\right)\end{array}$ & $\begin{array}{l}\mathrm{T}_{\min }{ }^{\ddagger} \\
\left({ }^{\circ} \mathrm{C}\right)\end{array}$ & $\begin{array}{c}\mathrm{T}_{\text {mean }}{ }^{\mathrm{S}} \\
\left({ }^{\circ} \mathrm{C}\right)\end{array}$ & $\begin{array}{c}\mathrm{pp}^{\#} \\
(\mathrm{~mm})\end{array}$ & $\begin{array}{l}\text { RH } \\
(\%)\end{array}$ & $\begin{array}{l}\mathrm{SH}^{*} \\
(\mathrm{~h})\end{array}$ \\
\hline Bečej & $\mathrm{BC}$ & $45^{\circ} 37^{\prime} 05^{\prime \prime} \mathrm{N}$ & $20^{\circ} 02^{\prime} 06^{\prime \prime} \mathrm{E}$ & 23.4 & 11.8 & 17.5 & 48.2 & 68.5 & 7.7 \\
\hline Kikinda & $\mathrm{KI}$ & $45^{\circ} 49^{\prime} 28^{\prime \prime} \mathrm{N}$ & $20^{\circ} 27^{\prime} 33^{\prime \prime} \mathrm{E}$ & 23.2 & 11.6 & 17.3 & 43.6 & 68.9 & 8.1 \\
\hline Pančevo & PA & $44^{\circ} 51^{\prime} 49^{\prime \prime} \mathrm{N}$ & $20^{\circ} 39^{\prime} 33^{\prime \prime} \mathrm{E}$ & 23.7 & 11.7 & 17.3 & 54.9 & 70.6 & 7.7 \\
\hline $\begin{array}{l}\text { Rimski } \\
\text { Šančevi }\end{array}$ & RS & $45^{\circ} 19^{\prime} 51^{\prime \prime} \mathrm{N}$ & $19^{\circ} 50^{\prime} 59^{\prime \prime} \mathrm{E}$ & 23.1 & 11.5 & 17.2 & 60.9 & 73.2 & 7.8 \\
\hline $\begin{array}{l}\text { Sremska } \\
\text { Mitrovica }\end{array}$ & SM & $44^{\circ} 59^{\prime} \mathrm{N}$ & $19^{\circ} 37^{\prime} \mathrm{E}$ & 23.5 & 11.4 & 17.0 & 62.9 & 77.5 & 7.3 \\
\hline Sombor & $\mathrm{SO}$ & $45^{\circ} 46^{\prime} 27^{\prime \prime} \mathrm{N}$ & $19^{\circ} 06^{\prime} 44^{\prime \prime} \mathrm{E}$ & 23.6 & 10.9 & 16.8 & 62.7 & 68.0 & 7.4 \\
\hline $\begin{array}{l}\text { Zemun } \\
\text { Polje }\end{array}$ & $\mathrm{ZP}$ & $44^{\circ} 52^{\prime} \mathrm{N}$ & $20^{\circ} 19^{\prime} \mathrm{E}$ & 23.1 & 12.4 & 17.7 & 60.7 & 74.0 & 7.1 \\
\hline Zaječar & $\mathrm{ZA}$ & $43^{\circ} 54^{\prime} 15^{\prime \prime} \mathrm{N}$ & $22^{\circ} 17^{\prime} 05^{\prime \prime} \mathrm{E}$ & 23.7 & 10.1 & 16.6 & 43.3 & 72.5 & 6.8 \\
\hline
\end{tabular}

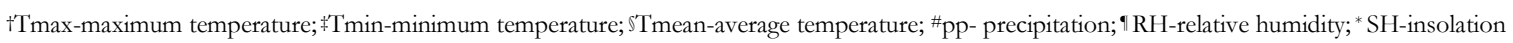

The experimental design was a randomized complete block design with four replications and elementary plot size was $10 \mathrm{~m}^{2}$. Standard cultural and agronomic practices generally used were applied at all locations. Nitrogen, phosphorus, and potassium, were added according to fertilizer recommendations for each location. Density of tested hybrids was 57.142 plants ha-1. Grain yield evaluation was performed by measurement of ears mass for each elementary plot using average sample from each replication and grain yield with $14 \%$ moisture ha ${ }^{-1}$ was calculated.

Additional information on climatic variables during vegetation period from April 15 to October 15 was provided by the Republic Hydrometeorological Service of Serbia. Maximum temperature, minimum temperature, mean temperature, precipitation, relative humidity and insolation duration average values for test locations are given (Table 2). 
For the data analysis a two-way fixed effect ANOVA was used based on randomized complete block design (RCBD) and the model is as follows:

$$
y_{i j k}=\mu+\gamma_{j k}+g_{i}+e_{j}+(g e)_{i j}+\varepsilon_{i j k}
$$

where $\mathcal{Y}_{i j k}$ is the grain yield response of $i_{\text {th }}$ hybrid in $j_{\text {th }}$ location for $k_{\text {th }}$ block; $\mu$ is the grand mean, $g_{i}$ is the effect of the $i$ th hybrid, $e_{j}$ is the effect of the $j_{\text {th }}$ location, $(g e)_{i j}$ is the interaction effect of the $i_{\text {th }}$ hybrid with $j$ th location and $\varepsilon_{i j k}$ is the error term associated with response variable. All effects in model were considered as fixed.

In order to evaluate hybrids for their performance and stability both hybrid $(\mathrm{G})$ and hybrid by location interaction (GL) effects must be considered simultaneously, and we used the sites regression (SREG) model (Crossa \& Cornelius 1997) to obtain GGL biplots. Data analysis was done within an $\mathrm{R}$ computing environment ( $\mathrm{R}$ Development Core Team 2010). The average-site coordination (ASC) view of the GGL biplot was used to estimate mean performance and stability of tested hybrids. The GGL biplot for this purpose originated using genotypemetric preserving singular value procedure $(\mathrm{SVP}=1)$ and is, therefore, more appropriate for hybrids evaluation.

A yield-stability statistic $\left(\mathrm{YS}_{\mathrm{i}}\right)$ developed for simultaneous selection of yield and stability was calculated according to Kang (1993). Location means of hybrids were subjected to stability analysis using Kang \& Magari's (1995) program 'STABLE' to obtain estimates of $\mathrm{YS}_{\mathrm{i}}\left(\right.$ Kang 1993) and $\sigma_{i}^{2}$ (Shukla 1972). The STABLE program also provided a partition of the total $\mathrm{G} \times \mathrm{L}$ interaction into heterogeneity (nonadditivity or the linear effect of environmental index
(EI);EI $=\bar{X}_{. j}-\bar{X}_{. .}$, where $\bar{X}_{. j}$ is mean of all hybrids in the location $j$ and $\bar{X}_{\text {.. is mean of all hybrids across }}$ all locations) and residual $\mathrm{G} \times \mathrm{L}$ interaction.

\section{Results and Discussion}

In consideration to the fact that the most stable genotype(s) may not be the highest yielding, the use of methods that integrate yield performance and stability to select superior genotypes becomes more important and advantageous, especially when target environment encompasses great range of environmental conditions (Kang \& Magari 1995). If high yielding maize hybrids with stable performance across environments are identified, the need for regional breeding strategy in order to exploit the positive GE interaction, would be reduced and lead to the preservation of breeders resources (Ceccarelli et al. 1994). In this study integration of mean yield performance and stability of experimental maize hybrids is achieved by SREG biplot methodology and Kang's yield-stability statistic $\mathrm{YS}_{\mathrm{i}}$.

ANOVA analysis showed highly significant $(P$ $<0.01)$ location effect that accounted for $82.9 \%$, of the total sum of squares for grain yield variation in the set of tested locations, (Table 2). The variance due to location effect is regarded as irrelevant for genotype evaluation in MET and is removed from the observed phenotypic data in order to focus on genotype $(G)$ and genotype $\times$ environment (GE) effects, which are relevant for genotype evaluation (Yan \& Kang 2003). Both YS and GGE methodology are based on the $G+G E$ (Setimela et al. 2007). Hybrid (G) and hybrid $\times$ location (GL) captured $9 \%$ and $8.1 \%$ (Table 2), respectively, in the set of tested locations.

Table 2. ANOVA for yield data obtained from maize multi-location trial conducted in Serbia

\begin{tabular}{lccccc}
\hline Source of variation & df & SS & SS $(\%)^{\dagger}$ & MS & $F$ value \\
\hline Total & 167 & 6405.95 & & & $7.78^{* *}$ \\
Hybrids $(G)$ & 20 & 576.50 & 9.0 & 28.82 & $983.44^{* *}$ \\
Locations $(\mathrm{L})$ & 7 & 5311.00 & 82.9 & 758.72 & $4.80^{* *}$ \\
G $\times$ L & 140 & 518.44 & 8.1 & 3.70 & 1.54 \\
Heterogeneity & 20 & 106.10 & 1.7 & 5.30 & $4.45^{* *}$ \\
Residual G $\times$ L & 120 & 412.35 & 6.4 & 3.44 & 0.77 \\
Pooled error & 480 & & & & \\
\hline
\end{tabular}

** $P<0.01 ; \dagger$ tested with respective mean square error term

The partitioning of GL interaction into heterogeneity caused by environmental index and residual GL interaction revealed that the linear effect of EI accounted for $1.7 \%$, (Table 2) but it was statistically non-significant. Residual $G \times L$ obtained after heterogeneity caused by EI is removed was highly significant $(P<0.01)$ and accounted for $6.4 \%$ of the total sum of squares (Table 2). The use of covariates, which can be any environmental factor such as humidity, precipitation, temperature, or environmental index, allows researchers to investigate possible causes of GEI (Magari \& Kang 1993). In our study the partitioning of GL interaction into heterogeneity caused by EI and residual GL interaction revealed that the linear effect of EI was statistically nonsignificant. Obtained results suggested that the cause of these interactions must be factors other than those captured by the linear effect of the environmental index. This is in accordance with 
the results of Fan et al. (2007) who conducted maize MET trials in China and also observed no significant heterogeneity caused by environmental index. Kang \& Gorman (1989) found heterogeneity caused by environmental index to be significant for the maize MET in a Louisiana, but individual weather factors (e.g., rainfall, humidity, temperature) did not cause significant heterogeneity. Magari \& Kang (1993) estimated contribution of environmental index, minimum temperature, maximum temperature, preseason rainfall, rainfall during the growing season, and relative humidity to GEI by determining heterogeneity attributable to each of these covariates. They found that in five of eight trials, heterogeneity due to environmental index was significant. Heterogeneity due to the other environmental factors was not significant in any trial. When heterogeneity is significant statistically, it means that the linear effect of EI influenced stability of cultivars. In such cases, genotypes-wise comparisons of $\sigma_{i}^{2}$ (Shukla 1972), stability-variance statistic derived from the total genotype $\times$ location (GL) interaction, and $\mathrm{S}_{\mathrm{i}}^{2}$ (Kang \& Miller 1984), stability-variance statistic derived from residual GL after removal of heterogeneity, caused by EI or by another covariate from total GL, is desirable (Kang et al. 2005).

The average-site coordination view of the site regression biplot was used to estimate mean performance and stability of tested hybrids. The ASC abscissa is the average location axis, and the projection of the hybrids markers onto this line represents the main effects of the hybrids (G) (Yan \& Tinker 2006). The ASC ordinate expresses the hybrids' contributions to GL effect, and thus is convenient for estimation of hybrids stability of performance (Yan \& Tinker 2006). According to Yan et al. (2001) ideal genotypes should have large projections of their markers towards the ASC abscissa to show high performance and small, preferably zero projection onto the ASC ordinate to show high stability of performance. Plant breeders and agronomists have found SREG biplot analysis to be useful for genotype evaluation (Butron et al. 2004, Malvar et al. 2005, Preciado-Ortiz et al. 2006, Fan et al. 2007).

GGL biplot explained $77.8 \%$ of the total G+GL variation for the set of all tested locations (Fig. 1). The length of the average-location vector was sufficient to select hybrids based on mean yield performance. Hybrids with above-average mean yield performance were G14, G5, G12, G3, G17, G8, G2, G18, G11, G1, G9 and G13, whereas hybrids with below-average mean yield were: G4, G6, G15, G10, G20, G16, G19, G7, G21. Hybrid G13 was with the highest mean yield performance and also the most stable hybrid. Hybrids G9, G2, G17 and G3 also showed good above-average mean yield performance and good stability. Hybrids with below-average mean yield performance showed greater instability in comparison to the hybrids with aboveaverage mean yield performance for the set of all tested locations. The least stable hybrid of all tested was G6 which also showed second worst mean yield performance.

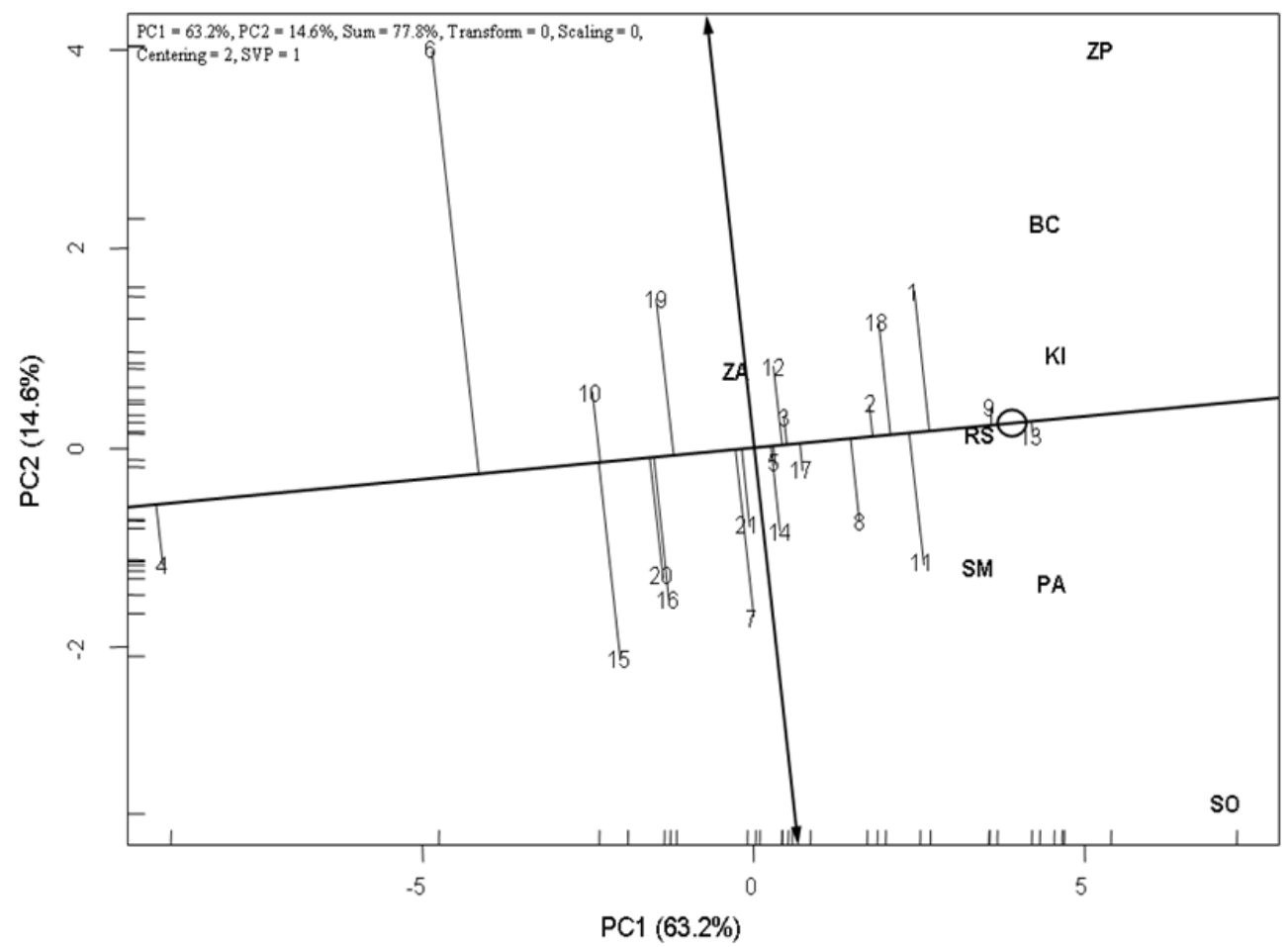

Figure 1. The average-environment coordination (AEC) view to show the mean performance and stability of hybrids. The details for test locations and hybrids are given in Tables 1 and 2 . 
According to Kang's analysis, a genotype with $\mathrm{YS}_{\mathrm{i}}$ statistics more than mean $\mathrm{YS}_{\mathrm{i}}$ and non-significant stability variance (Shukla 1972) is ideal for selecting genotypes for both high yield and stability. The mean $\mathrm{YS}_{\mathrm{i}}$ value was 4.71 and 12 hybrids with $\mathrm{YS}_{\mathrm{i}}>4.71$ had potential for further testing (Table 3). The mean grain yield of these hybrids was $14.02 \mathrm{t} \mathrm{ha}^{-1}$, which is statistically equal to the mean yield $\left(13.98 \mathrm{t} \mathrm{ha}^{-1}\right)$ of the 13 hybrids that could be selected on the basis of their grain yields alone (grain yield of hybrid $>$ mean trial yield) (Table 3). Of the 21 tested hybrids G3 and G17 showed non-significant stability variance $\left(\sigma_{i}^{2}\right)$ and $\mathrm{YS}_{\mathrm{i}}$ values higher than the mean $\mathrm{YS}_{\mathrm{i}}$ (Table 3 ). The mean grain yield of these two hybrids was $13.61 \mathrm{t}$ $\mathrm{ha}^{-1}$. On this basis, only two hybrids with good stability and high grain yields can be recommended. Bertoia et al. (2002) identified maize inbred lines with improved ear and stover yield and quality of silage using $\mathrm{YS}_{\mathrm{i}}$. The integration of yield and stability using $\mathrm{YS}_{\mathrm{i}}$ statistics helps to identify genotypes that perform well for both grain yield and stability, and also reduces the probability of committing Type II errors. A consequence of committing a Type I error would be that growers could miss using a stable genotype, but the consequence of committing a Type II error could be disastrous for growers as they might grow an unstable genotype and suffer economically (Kang 1993). It also helps to reduce the number of genotypes recommended for Advanced Trials and Official Variety Trials selected solely on mean grain yield, thus saving the total testing costs of METs. Kang (1993) showed that selecting for yield and stability will not automatically result in lower yield but if high yielding, unstable genotypes are used under poor environment conditions it can cause crop failures. Although $\mathrm{YS}_{\mathrm{i}}$-based selection would continue to identify unstable genotypes, the number of unstable genotypes selected is usually fewer than that identified by selection based on yield alone and when significant interaction is present, selection process becomes more precise (Kang \& Magari 1995).

Table 3. Yield stability statistics $\left(\mathrm{YS}_{\mathrm{i}}\right)$ for simultaneous selection for mean grain yield ( $\left.\mathrm{t} \mathrm{ha} \mathrm{a}^{-1}\right)$ and stability of 21 experimental maize hybrids across the set of all the tested locations in 2004

\begin{tabular}{|c|c|c|c|c|c|c|c|}
\hline Hybrid & $\begin{array}{c}\text { Mean } \\
\text { grain yield } \\
\left(\mathrm{t} \mathrm{ha}^{-1}\right)\end{array}$ & $\begin{array}{l}\text { Yield } \\
\text { rank } \\
(Y \#)\end{array}$ & $\begin{array}{c}\text { Adjustment } \\
\text { to } \\
\mathrm{Y \# a}\end{array}$ & $\begin{array}{c}\text { Adjusted } \\
\mathrm{Y} \\
(\mathrm{Y})\end{array}$ & $\begin{array}{c}\text { Stability } \\
\text { variance } \\
\qquad\left(\sigma_{i}^{2}\right)\end{array}$ & $\begin{array}{c}\text { Stability } \\
\text { rating }(\mathrm{S})\end{array}$ & $\mathrm{YS}_{\mathrm{i}}=(\mathrm{Y}+\mathrm{S})$ \\
\hline G1 & 14.38 & 19 & 3 & 22 & $1.41^{*}$ & -2 & $20^{+}$ \\
\hline G2 & 13.96 & 16 & 2 & 18 & $3.22^{* * *}$ & -8 & $10^{+}$ \\
\hline G3 & 13.69 & 13 & 1 & 14 & 0.96 & 0 & $14^{+}$ \\
\hline G4 & 10.49 & 1 & -3 & -2 & $8.02^{* * *}$ & -8 & -10 \\
\hline G5 & 13.64 & 12 & 1 & 13 & $3.79^{* * *}$ & -8 & $5^{+}$ \\
\hline G6 & 12.08 & 2 & -3 & -1 & $15.71^{* * *}$ & -8 & -9 \\
\hline G7 & 13.50 & 9 & 1 & 10 & $3.44^{* * *}$ & -8 & 2 \\
\hline G8 & 13.82 & 15 & 2 & 17 & $2.62^{* * *}$ & -8 & $9^{+}$ \\
\hline G9 & 14.45 & 20 & 3 & 23 & $4.72^{* * *}$ & -8 & $15^{+}$ \\
\hline G10 & 12.72 & 4 & -2 & 2 & $2.75^{* * *}$ & -8 & -6 \\
\hline G11 & 14.30 & 17 & 3 & 20 & $2.35^{* * *}$ & -8 & $12^{+}$ \\
\hline G12 & 13.78 & 14 & 1 & 15 & $2.78^{* * *}$ & -8 & $7^{+}$ \\
\hline G13 & 14.74 & 21 & 3 & 24 & $4.68^{* * *}$ & -8 & $16^{+}$ \\
\hline G14 & 13.60 & 11 & 1 & 12 & $1.36^{*}$ & -2 & $10^{+}$ \\
\hline G15 & 12.66 & 3 & -3 & 0 & $2.66^{* * *}$ & -8 & -8 \\
\hline G16 & 12.97 & 6 & -2 & 4 & $4.55^{* * *}$ & -8 & -4 \\
\hline G17 & 13.53 & 10 & 1 & 11 & 1.24 & 0 & $11^{+}$ \\
\hline G18 & 14.31 & 18 & 3 & 21 & $2.65^{* * *}$ & -8 & $13^{+}$ \\
\hline G19 & 12.93 & 5 & -2 & 3 & $3.08^{* * *}$ & -8 & -5 \\
\hline G20 & 13.18 & 7 & -1 & 6 & $3.42^{* * *}$ & -8 & -2 \\
\hline G21 & 13.33 & 8 & -1 & 7 & $2.32^{* * *}$ & -8 & -1 \\
\hline Mean & 13.43 & & & & & & 4.71 \\
\hline
\end{tabular}

a Adjustment to $\mathrm{Y \#} \mathrm{(+} 1$ for mean yield $>$ overall mean yield $(\mathrm{OMY}),+2$ for mean yield $>1$ LSD above OMY, +3 for mean yield $>2$ LSD above OMY, -1 for mean yield $<$ OMY, -2 for mean yield $<1$ LSD below OMY, -3 for mean yield $<2$ LSD below OMY); *** $\mathrm{P}<0.01$; ** $\mathrm{P}<$ $0.05 ;{ }^{*} \mathrm{P}<0.1 ;{ }^{+}$Genotype selected on the basis of $\mathrm{YS}_{\mathrm{i}}$ 
Out of 21 hybrids tested in the set of all tested locations, two hybrids showed non-significant stability variance $\left(\sigma_{i}^{2}\right)$ and $\mathrm{YS}_{\mathrm{i}}$ values higher than the mean $\mathrm{YS}_{\mathrm{i}}$ (Table 3). On this basis, only two hybrids with good stability and high grain yields can be recommended. If the decisions were based only on mean hybrids performance, then also the rest of 11 hybrids (grain yield of hybrid $>$ mean trial yield) would have been recommended, leading to a Type II error or to a biological or static concept of stability (Becker \& Leon 1988). This concept is not acceptable to most breeders and agronomists who would prefer an agronomic or dynamic concept of stability favouring the high yielding genotypes which has a potential to respond positively to agronomic inputs or better environmental conditions (Becker 1981, Becker \& Leon 1988).

GGL biplot for the set of all tested locations also confirmed good stability and above-average mean yield performance (Fig. 1) of these two selected hybrids, although also showed seven more hybrids with higher mean yield performance, and two of these seven hybrids were with better stability. Yan \& Kang (2003) and Fan et al. (2007) reported a highly significant association between rankings of genotypes based on mean performance and stability in the SREG biplot and genotype ranking based on the $\mathrm{YS}_{\mathrm{i}}$ statistic.

\section{Conclusions}

The average-site coordination (ASC) view of the GGL biplot and Kang's yield stability statistic-YS were confirmed in our study as appropriate tools to integration and estimation of maize hybrid's mean performance and stability. On the basis of the $\mathrm{YS}_{\mathrm{i}}$ statistic two hybrids with good stability and high grain yields can be recommended, and regarding GGL biplot two same hybrids and two more, not confirmed as stable by the $\mathrm{YS}_{\mathrm{i}}$ statistic.

Although both used models allows interpretation of agronomic or dynamic concept of stability, we recommend the sites regression biplot as more informative and precise tool for simultaneous hybrids mean performance and stability estimation.

\section{References}

Annicchiarico, P. (2002). Defining adaptation strategies and yieldstability targets in breeding programmes. In: M.S. Kang (Ed.), Quantitative Genetics, Genomics and Plant Breeding (pp. 365-385). New York: CAB International.

Becker, H.C. (1981). Correlations among some statistical measures of phenotypic stability. Euphytica 30: 835-840.

Becker, H.C., \& Leon, J. (1988). Stability analysis in plant breeding. Plant Breeding 101: 1-23.

Bertoia, L.M., Burak, R., \& Torrecilla, S.M. (2002). Identifying inbred lines capable of improving ear and stover yield and quality of superior silage maize hybrids. Crop Science 42: 365372.

Butron, A., Velasco, P., Ordas, A., \& Malvar, R.A. (2004). Yield evaluation of maize cultivars across environments with different levels of pink stem borer infestation. Crop Science 44: 741-747.

Ceccarelli, S., Erskine, W., Hamblin, J., \& Grando, S., (1994). Genotype by environment interaction and international breeding programs. Experimental Agriculture 30: 177-187.

Comstock, R.E., \& Moll, R.H. (1963). Genotype-environment interactions. In: W.D. Hanson and H.F. Robinson (Eds.), Statistical Genetics and Plant Breeding. Publication 982 (pp. 164196). Washington DC, National Academy of Sciences.

Crossa, J., \& Cornelius, P.L. (1997). Sites regression and shifted multiplicative model clustering of cultivar trial sites under heterogeneity of error variances. Crop Science 37: 405-415.

Fan, X.M., Kang, M.S., Chen, H., Zhang, Y., Tan, J., \& Xu, C., (2007). Yield stability of maize hybrids evaluated in multienvironment trials in Yunnan, China. Agronomy J. 99: 220-228.

Gauch, H.G., \& Zobel, R.W. (1997). Identifying megaenvironments and targeting genotypes. Crop Science 37: 311-326.

Gravois, K.A., \& Bernhardt, J.L. (2000). Heritability and genotype $\times$ environment interactions for discolored rice kernels. Crop Science 40: 314-318.

Haynes, K., Wilson, D.R., \& Kang, M.S. (1995). Genotype × environment interactions for specific gravity in diploid potatoes. Crop Science 35: 977-981.

Kang, M.S., \& Miller, J.D. (1984). Genotype $\times$ environment interactions for cane and sugar yield and their implications in sugarcane breeding. Crop Science 24: 435-440.

Kang, M.S., \& Gorman, D.P. (1989). Genotype $\times$ environment interaction in maize. Agronomy J. 81: 662-664.

Kang, M.S. (1991). Modified rank-sum method for selecting high yielding, stable crop genotypes. Cereal Research Communications 19: 361-364.

Kang, M.S. (1993). Simultaneous selection for yield and stability in crop performance trials: Consequences for growers. Agronomy J. 85: 754-757.

Kang, M.S., \& Magari, R. (1995). New developments in selecting for phenotypic stability in crop breeding. In: M.S. Kang and H.G. Gauch (Eds.), Genotype by Environment Interaction (pp. 114). Boca Raton, Florida: CRC Press.

Kang, M.S., Aggarwal, V.D., \& Chirwa R.M. (2005). Adaptability and stability of bean cultivars as determined via yield-stability statistic and GGE biplot analysis. J.of Crop Improvement 15: 97120.

Kempton, R.A., \& Fox, P.N. (1997). Statistical methods for plant variety evaluation. Chapman \& Hall, London.

Madry, W. (2003). Yield-stability statistics for selecting sidelyadapted genotypes of spring wheat and oat. Journal of New Seeds 5: 43-56.

Magari, R., \& Kang, M.S., (1993). Genotype selection via a new yield stability statistic in maize yield trials. Euphytica 70: 105111.

Malvar, R.A., Revilla, P., Butrona, A., Gouesnardc, B., Boyatc, A., Soengasa, P., Alvarezb, A., \& Ordas, A. (2005). Performance of crosses among French and Spanish maize populations across environments. Crop Science 45: 1052-1057.

Mekbib, F. (2003). Yield stability in common bean (Phaseolus vulgaris L.) genotypes. Euphytica 130: 147-153.

Pazdernik, D.L., Hardman, L.L., \& Orf, J.H. (1997). Agronomic performance and stability of soybean varieties grown in three maturity zones in Minnesota. J. of Production Agriculture 10: 425430.

Preciado-Ortiz, R., Guerrero, R., Ortega, A., Terron, A., Crossa, J., Cordova, H., Reyes, C., Aguilar, G., Tut, C., Gomez, N., \& Cervantes, E. (2006). Identification of superior quality protein maize hybrids for different mega-environments using the biplot methodology. Maydica 51: 451-461.

R Development Core Team (2010). R: A Language and Environment for Statistical Computing, R Foundation for Statistical Computing, Vienna, Austria. http://www.R-project.org.

Setimela, P.S., Vivek, B., Bänziger, M., Crossa, J., \& Maideni, F. (2007). Evaluation of early to medium maturing open pollinated maize varieties in SADC region using GGE biplot based on the SREG model. Field Crop Research 103: 161-169. 
Shukla, G.K. (1972). Some statistical aspects of partitioning genotype-environmental components of variability. Heredity 29: $237-245$

Upadhya, M.D., \& Cabello, R. (2000a). Selection of parental lines using stability analysis of bybrid true potato seed families produced through line $\times$ tester method (pp. 197-206). CIP, Lima, Peru: CIP Program Report 1999-2000.

Upadhya, M.D., \& Cabello, R. (2000b). Influence of seed size and density on the performance of direct seedling transplants from bybrid true potato seed (pp.207-210). CIP, Lima, Peru: CIP Program Report 1999-2000.

Waldron, B., Asay, K.H., \& Jensen, K.B. (2002). Stability and yield of cool-season pasture grass species grown at five irrigation levels. Crop Science 42: 890-896.

Yan, W., Hunt, L.A., Sheng, Q., \& Szlavnics, Z. (2000). Cultivar evaluation and mega-environment investigation based on GGE biplot. Crop Science 40: 597-605.

Yan, W., Cornelius, P.L., Crosssa, J., \& Hunt, L.A. (2001). Two types of GGE biplots for analyzing multi-environment trial data. Crop Science 41: 656-663.

Yan, W., \& Hunt, L.A. (2003). Biplot analysis of multi-environment trial data. In: M.S. Kang (Ed.), Quantitative Genetics, Genomics, and Plant Breeding (pp. 289-303). Wallingford, Oxon, UK: CAB International.

Yan, W., \& Kang, M.S. (2003). GGE biplot analysis: A graphical tool for breeders, geneticists, and agronomists. Boca Raton, London, New York Washington, DC: CRC Press.

Yan, W., \& Tinker, N.A. (2006): Biplot analysis of multienvironment trial data: Principles and applications. Canadian J. of Plant Science 86: 623-645

\section{Poređenje biplot analize i Kangove statistike stabilnosti $\left(\mathrm{YS}_{\mathrm{i}}\right)$ u proceni stabilnosti hibrida kukuruza}

\section{Miroslav Zorić · Bojan Mitrović · Dušan Stanisavljević · Mile Ivanović Goran Bekavac · Dalibor Živanov · Milan Mirosavljević}

Sažetak: Istovremena procena prinosa i stabilnosti prinosa na osnovu rezultata iz multi-lokacijskih ogleda ima veliki značaj u preporuci hibrida kukuruza. Cilj ovog istraživanja bio je da se ispita (i) prinos i stabilnost prinosa eksperimentalnih hibrida kukuruza pomoću Kangove statistike stabilnosti (YSi) i metodom SREG GGL biplot analize, na osnovu podataka iz multi-lokacijskih ogleda u Srbiji, i (ii) da li su linearni efekti indeksa spoljašnjih sredina uticali na stabilnost hibrida. Glavni efekti genotipa (hibrida) bili su visoko značajni i obuhvatali su $9 \%$ od ukupne sume kvadrata. Interakcija hibrid $\times$ lokalitet je takođe bila visoko značajna i obuhvatala je $8,1 \%$ od ukupne sume kvadrata. Heterogenost uslovljena razlikom između spoljašnjih sredina bila je statistički neznačajna. $\mathrm{Na}$ osnovu rezultata obe analize isti genotipovi su izdvojeni kao stabilni ali je prednost na strani SREG modela kao preciznijeg i informativnijeg.

Ključne reči: GGL biplot, hibridi, kukuruz, prinos zrna, stabilnost prinosa, YSi statistika 